Indonesian Journal of Islamic Psychology

Volume 1. Number 2, December 2019 (p-ISSN: 2685-1482 e-ISSN 2714-7576)

website: http://e-journal.iainsalatiga.ac.id/index.php/ijip/index

\title{
Model Dakwah dalam Pelayanan Pasien
}

\section{Reza Ahmadiansah ${ }^{*}$}

Institu Agama Islam Negeri Salatiga, Indonesia

\section{Abstract}

This Research aimed at knowing the model of Da'wah in patient service conducted in the public hospital of Salatiga and hospital of Dr. Asmir Salatiga.this research Used a qualitative research approach. The results of this research showed that (1) the Patient service of counselors given by RSUD Salatiga had been conducted since 2010. With a seven-person counselor. The Model of Da'wah was used in serving the patient guidance by promoting religious spirituallitas such as dhikr, prayers and so on. (2) The implementation of Da'wah conducted by the hospital of Dr. Asmir Salatiga to the needs of the patients when requiring counseling for psychiatric, or sedative ruhani when they abused by many severe diseases, or some other problems, such as conducting guidance or direction which was of nature to make comfort in the psychic patients.

Keywords: da'wah; excellent service; patients; counselor

\begin{abstract}
Abstrak
Penelitian bertujuan untuk mengetahui model dakwah dalam pelayanan pasien yang dilaksanakan di rumah sakit umum daerah Salatiga dan rumah sakit dr. Asmir Salatiga. Dengan menggunakan pendekatan penelitian kualitatif. Hasil penelitian ini menunjukkan bahwa (1) Pelayanan pasien konselor yang diberikan oleh RSUD Salatiga sudah dilakukan sejak tahun 2010. Dengan tenaga konselor berjumlah tujuh orang. Model dakwah yang digunakan dalam melayani pasiennya bimbingan dengan mengedepankan spirituallitas agama seperti dzikir, doa dan sebagainya. (2) Pelaksanaan dakwah yang dilakukan oleh pihak rumah sakit dr Asmir Salatiga terhadap kebutuhan pasien ketika membutuhkan konseling bagi kejiwaan, atau penenang ruhani mereka saat dirundung banyak penyakit yang berat, atau beberapa masalah yang lainnya, misalnya melakukan bimbingan atau arahan yang sifatnya untuk membuat kenyamanan dalam psikis pasien.
\end{abstract}

Kata Kunci: dakwah; pelayanan; pasien; konselor

*Corresponding Author

rezaahmadiansah@iainsalatiga.ac.id 


\section{Pendahuluan}

Layanan yang diberikan kepada pasien di rumah sakit ternyata bukanlah hal yang baru, jauh sebelumnya sudah banyak yang melakukan penelitian terhadap pelayan yang dikemas berbentuk dakwah atau bisa juga disebut dengan pelayan rohani, spiritual. Kesemuanya itu adalah dengan menggunakan ajaran-ajaran agama Islam supaya para pasien yang diberikan pelayanan seperti itu dapat membantu meringankan penderitaan yang diamainya secara psikologis.

Menurut Seber (dalam Arifin, 2012) mengungkapkan ada beberapa hasil penelitian dalam masalah ini, seperti dari Marsh dan Barr tahun 1975 Pietroni dan Vaspe tahun 2000, tulisan dari Thomas, Davidson, dan Rance tahun 2001. Pandangan umum dari hasil penelitian ini menyimpulkan bahwa perawatan dan penyembuhan pasien di rumah sakit bukan hanya persoalan aspek medis saja, melainkan membutuhkan pendekatan secara holistik-komprehensif, sejalan dengan standar sehat menurut organisasi kesehatan dunia World Health Organization (WHO) 1984 menjelaskan harus meliputi aspek bio-psiko-sosio-spiritual. Sedangkan menurut Hawari (2011) mengungkapkan bahwa pentingnya aspek spiritual dalam menunjang pengobatan aspek lainnya tidak dapat ditawar-tawar lagi, sebab bermacam-macam dari hasil penelitian yang terkini menunjukkan bahwa pengaruh spiritual terhadap kesehatan dan kesembuhan pasien sangatlah penting, oleh karena itu sangatlah dibutuhkan.

Dakwah merupakan proses ajakan pada manusia tentang kebaikan, dalam hal ini diwajibakkan bagi umat Islam. Namun tidak menutup kemungkinan pula disampaikan kepada orang lain selian muslim. Dakwah bisa dilakukan dimana saja tanpa terikat ruang dan waktu. Hal ini karena pada dasarnya dakwah adalah kebutuhan manusia sebagai mahluk 
$\overline{\text { religius yang setiap saat harus terpenuhi demi keberlangsungan hidup }}$ mencapai kebahagian dunia akhirat (Hidayanti, 2014). Tidak terkecuali pula di rumah sakit - rumah sakit yang tentunya banyak orang yang membutuhkan penguatan secara mental terhadap penyakit yang diderita oleh seseorang. Itulah sebab dakwah menjadi suatu kebutuhan yang sangat diperlukan, karena sebagai wadah pelayanan umum kesehatan masyarakat, maka setiap rumah sakit selalu berupaya untuk memenuhi dan memberikan layanan nomor satu kepada konsumen (pasien) supaya puas.

Keberadaan dakwah dalam layanan kepada pasien yang dikembangkan pada setiap rumah sakit umum utamanya kota Salatiga sangatlah diperlukan, karena setiap pasien memiliki keluhan serta kegelisahan yang berbeda-beda. Maka dari itu pihak rumah sakit harus menyediakan pelayanan tersebut supaya penderitaan mereka tidak terlalu berat dalam memikirkan penyakit yang mereka derita.

Dalam konteks dakwah konselor, dan perawat memilki peran strategis dimana ia berinteraksi secara langsung serta terus menerus dalam menjalankan tugasnya, oleh karenanya dakwah berjalan dengan baik jika konselor atau perawat melakukan tugasnya bersamaan dengan dakwah, namun fenomena ini tidak seperti yang seharusnya karena seorang perawat akan lebih fokus pada persoalan perawatan pengobatan pada pasien.

Pesan-pesan perawat atau petugas konselor yang disampaikan kepada pasien tentunya mampu memberikan motivasi yang mampu memberikan semangat untuk bangkit dan kuat melawan penyakit yang diderita oleh pasien. Maka dari itu pelayanan terhadap pasien melalui unsur psikis setidaknya mampu memberikan energi positif untuk bangkit dalam melawan penyakit yang dialami. Dakwah yang disampaiakan itu 
merupakan bagian dari terapi secra psikologis yang disampaikan oleh konselor, selain terapi secara medis yang diberikan oleh dokter maupun perawat kesehatan.

Beberapa model-model dakwah dalam penerapan pelayanan pada pasien diantaranya adalah bi-al-irsyād. (Arifin \& Satriah, 2018). Dalam dakwah bi-al-irsyād ini supaya secara mental kesehatan pasien tetap terjaga. Maka dengan adanya pelayanan model dakwah terhadap pasien seperti ini kesehatan mental pasien tetap terjamin dan secara kontinyu. Adapun manfaat dari model dakwah ini adalah sebagai berikut: 1) pembimbing rohani pasien agar senantiasa berada dalam fitrahnya dengan menjaga pelaksanaan kewajiban agamanya terutama ibadahnya selama sakit, 2) membimbing pasien agar memiliki semangat dalam menjalani hidup meskipun dalam kondisi sakit parah, menyadari kelemahan dirinya sebagai makhluk Allah, mengakui kekuasaan dan takdir Allah atas dirinya, bersikap dan berperilaku sesuai dengan ajaran agama Islam, 3) membimbing pasien agar mengetahui urgensi dan esensi ibadah, berdoa, mengetahui cara berdoa yang baik dan benar, bisa berdoa dengan baik dan benar, 4) membimbing pasien dalam hal beribadah agar pasien mengetahui dan memahami tata cara beribadah sekalipun dalam keadaan sakit, 5) membimbing pasien yang dalam menghadapi sakaratul maut agar wafat dalam keadaan husul khatimah, 6) membantu pasien agar dapat memecahkan permasalahan yang dihadapinya sehingga terjaga kesehatan mental sepiritualnya. (Arifin \& Satriah, 2018). Praktik dakwah yang dilakukan di rumah sakit dalam yang berbentuk layanan ada perbedaan terhadap model dakwah yang dilakukan karena harus mengikuti prosedural di rumah sakit tempat pasien dirawat. Sementara keperluan merawat kesehatan mental spiritual pasien sebagai mad'u sangat mendesak. 
Tujuan utama Rumah Sakit yaitu memberikan pelayanan kesehatan bersifat baik jasmani maupun rohani, terpadu dan professional dengan meningkatkan sumber daya rumah sakit dan masyarakat serta mengutamakan kepuasan masyarakat dalam pelayanannya, melaksanakan pelayanan kesehatan yang dalam aspek sumber daya insani. Rumah Sakit umum daerah Salatiga (milik pemerintah), rumah sakit (milik militer), dari masing-masing rumah sakit tersebut sebagai tujuan dalam rujukan pengobatan oleh masyarakat Kota Salatiga dan sekitar.

Kendala yang dihadapi dilapangan dalam persoalan dakwah adalah banyaknya pasien yang tidak memahami tentang pentingnya motivasi dalam penyembuhan melalui terapi atau dakwah Islami. Dari latar belakang di atas maka peneliti ingin menggali lebih dalam bagaimana model dakwah yang ada dalam pelayanan pasien di Rumah Sakit Kota salatiga.

\section{Model Dakwah}

Secara etimologi asal kata dakwah berasal dri bahasa Arab yang mengandung arti ajakan, seruan, serta panggilan. Sedangkan menurut tata bahasa Arab istilah kata dakwah adalah "isim masdhar" dari kata kerja “da'a, yadu'u, da'watan" yang mengandung makna mengajak, menyeru dan memanggil (Saputra, 2011).

Umar (dalam Ridla \& Rifa'i, 2017) mendefinisikan dakwah secara terminology ialah mengajak umat manusia secara baik dan bijaksana menuju jalan kebenaran yang sesuai seruan Allah SWT guna menggapai keselamatan baik di dunia maupun di akherat. Sedangkan menurut Amin (2009) dakwah adalah hal yang penting dalam setiap kehidupan pribadi Muslim, yang esensinya terletak pada seruan dorongan atau motivasi, 
stimulan dan bimbingan kepada orang-orang supaya menyambut ajaran Islam dengan penuh kesadaran demi keuntungan dirinya sendiri serta bukan pada kepentingan yang mengajaknya.

Dari penjelasan pengertian dakwah di atas, maka bisa dipahami bahwa pada dasarnya dakwah adalah usaha untuk mengajak, menyarankan manusia supaya sungguh-sungguh menerima petunjuk yang dijelaskan Islam.

\section{Model-model Dakwah}

Model adalah representasi dari suatu objek, benda atau ide-ide dalam bentuk yang disederhanakan dari kondisi fenomena alam. Model berisi informasi tentang suatu fenomena yang dibuat dengan tujuan untuk mempelajari fenomena sistem yang sebenarnya. Model dapat berupa tiruan dari suatu benda, sistem atau kejadian yang sesungguhnya yang hanya berisi informasi-informasi yang dianggap penting untuk ditelaah (Mahmud, 2008).

Adapun model-model dakwah diantaranya adalah (1) da'wah bil lisan. Dakwah model ini dapat melalui bentuk nasihat, diskusi, sarasehan, dan intinya melalui mulut atau lisan. Dimana, lanjutnya, materi da'wah bil lisan ini perlu ditingkatkan dan terus dilatih agar mampu menjawab tantangan zaman. (2) yakni da'wah bil qalam yaitu dakwah melalui bentuk tulisan dengan tema-tema yang aktual, menjawab pertanyaan masyarakat, dijawab melalui buku," sehingga dakwah bisa lebih menyebar bila diterbitkan dalam bentuk buku kecil yang disebarkan ke seluruh Indonesia sehingga masyarakat paham. (3) da'wah bil hal atau dengan aksi nyata. Dakwah dalam bentuk ini, Majelis Ulama Indonesia menekankan penyelenggaraan kegiatan-kegiatan bersifat sosial dan ekonomi (Nafsiah, 2000). 
Dari penjelasan diatas dapat disimpulkan bahwa model dakwah itu adalah acuan untuk mengajak orang melalukan perbuatan, melaksanakan ajaran yang sesuai dengan tuntunan serta ajaran yang disampaiakan oleh agama Islam.

\section{Pelayanan Pasien Rumah Sakit}

\section{Pengertian Pasien}

Berdasarkan pasal 1 ayat 4 undang-undang RI nomor 44 tahun 2009 tantang Rumah Sakit bahwa pasien adalah setiap orang yang melakukan konsultasi masalah kesehatannya untuk mendapatkan pelayanan kesehatan yang dibutuhkan, baik itu secara langsung maupun tidak langsung di Rumah Sakit. Sedangkan pasien merupakan seseorang yang menerima perawatan secara medis oleh perawat atau tenaga kesehatan baik itu memiliki kelemahan secara fisik maupun secra mental sehingga memercayakan keapada pihak lain tersebut, (Wilhamda, 2011).

Pohan (2007) mendefinisikan pelanggan layanan kesehatan merupakan orang yang melakukan kontak dengan layanan kesehatan. Terdapat dua macam pelanggan dalam layanan kesehatan, yakni pelanggan eksternal dan internal. Pelanggan eksternal adalah orang yang memperoleh layanan kesehatan namun berada di luar organisasi layanan kesehatan. Pasien dan keluarga pasien termasuk dalam pelanggan eksternal. Sedangkan pelanggan internal adalah orang yang bekerja di dalam organanisasi layanan kesehatan dan menghasilkan layanan kesehatan. Pasien sebagai pelanggan eksternal layanan kesehatan tidak hanya membutuhkan kesembuhan dari sakit, tetapi pasien juga merasakan dan menilai layanan kesehatan yang ia terima. 
Kesimpulan dari berbagai penjelasan mengenai pelanggan diatas, bahwa pelanggan (dalam hal ini adalah pasien) adalah pembeli atau pemakai produk atau jasa perusahaan sehubungan dengan kualitas dari kinerja perusahaan tersebut atau hasil kinerja produk atau jasa yang telah digunakan. Pelanggan dalam penelitian ini masuk dalam jenis konsumen eksternal mengingat bahwa pelanggan telah melakukan pembelian, penggunaan, dan merasakan akhir suatu produk atau jasa. Pelanggan dalam penelitian ini adalah konsumen sebagai pengguna atau penerima jasa layanan rumah sakit yang disebut sebagai pasien.

\section{Jenis Pasien}

Depkes RI, 2006 (dalam Ismainar, 2013) menjelaskna bahwa pasien di rumah sakit dapat dikategorikan sebagai pasien poliklinik (pasien berobat jalan) dan pasien rawat inap. Adapun jenis pasien yang datang ke rumah sakit: (1). Pasien yang dapat menunggu, (2). Pasien yang segera ditolong. Sedangkan menurut jenis kedatangannya pasien dapat dibedakan menjadi: (1). Pasien baru adalah pasien yang baru pertama kali datang ke rumah sakit untuk keperluan berobat atau, (2). Pasien lama adalah pasien yang pernah datang sebelumnya untuk keperluan berobat.

Adapun kedatangaan pasien ke rumah sakit dapat terjadi karena: (1). Dikirim oleh dokter praktek luar rumah sakit, (2). Dikirim oleh rumah sakit lain, Puskesmas atau jenis pelayanan kesehatan lain atau, (3). Datang atas kemauan sendiri.

Maka dari penjelasan di atas dapat disimpulkan bahwa jenis pasien dapat dikategorikan menjadi 2 (dua) yaitu pasien yang rawat inap dan pasien rawat jalan, yang semuanya itu akan mendapatkan hak yang sama namun khusu pasien yang dirawat 
inap, pasien akan mendapat pelayanan dari konselor (rohaniawan).

\section{Pelayanan di Rumah Sakit}

Rumah sakit merupakan tempat untuk mengobati pasien yang sedang mengalami sakit secara medis. Dalam pelayanannya (pengobatan) dilakukan oleh dokter yang ahli dibidangnya. Sebagaimana dijelaskan dalam UU No. 44 Tahun 2009 tentang rumah sakit, bahwa yang dimaksudkan dengan rumah sakit adalah: institusi pelayanan kesehatan yang menyelenggarakan pelayanan kesehatan perorangan secara paripurna yang menyediakan pelayanan rawat inap, rawat jalan, dan gawat darurat.

Berdasarkan hasil Lokakarya Nasional Keperawatan tahun 1983 (dalam Lestari, 2014) menjelaskan bahwa keperawatan yaitu sebuah wujud pelayanan keperawatan yang profisional adalah bagian integral dari pelayanan kesehatan berdasarkan ilmu dan kiat keperawatan berbentuk pelayanan boi-psiko-sosial-spiritual yang sangat komprehensif, ditujukan kepada individu, keluarga, serta masyarakat baik itu sakit maupun sehat dengan mencakup seluruh kehidupan manusia.

Maka disinilah perawat akan memberikan pelayanan secara komprehensif, baik itu dari segi pelayanan akan kebutuhan fisik, spiritual, psikologi, sosial dan pendidikan kepada pasien. Dengan demikian pelayanan keperawatan akan dapat dirasakan lebih sempurna oleh pasien, jadi tidak hanya secara fisik saja yang mendapatkan perhatian perawat.

Secara holistik keperawatan memandang manusia adalah sebagai mahluk biologik, psikologik, sosial dan spiritual. Kozier (dalam Kusnanto, 2005). 1). Mempunyai rumusan jasmaniah (fisik) 
yang disatukan oleh sistem organik, masing-masing organ memiliki fungsi, tunduk terhadap hukum alam, seperti lahir-berkembangmenua-kematian. 2). Manusia sebagai makhluk hidup tentunya mempunyai jiwa (psikologik), seperti ia diperintah, dipengaruhi oleh perasaan, dan memiliki daya pikir. 3). Manusia sebagai makhluk sosial, seperti, mereka hhidup ditengah-tengah masyarakat yang diatur oleh norma dan sistem nilainya, dan anggota keluarga, hingga masyarakat. 4). Sebagai makhluk hidup dengan dasaar spiritual, seperti mempunyai keyakinan dan kepercayaan terhadap Tuhan Yang Maha Esa.

\section{Kebutuhan Pasien}

Hardjodisastro (2006) menejelaskan bahwa kebutuhan pasien adalah tidak lain supaya ia lekas sembuh dari penyakitnya dengan sendirinya tidak dapat dilepaskan dari konsep kebutuhan manusia dalam teori Maslow dan yang relevan dalam pemecahan masalah medik adalah kebutuhan makan (nutrisi) dan minum, rasa dihargai dan diperhatikan haknya serta kebutuhan rasa aman dan nyaman (safe and secure). Selain kebutuhan akan nutrisi, pasien juga membutuhkan yang namanya kenyamanan dan ketenangan akan batin. Untuk memenuhi kebutuhan tersbut hendaknya nutrisi yang masuk kedalam rohaninya adalah religius atau lebih mendekatkan diri terhadap Allah SWT.

Jadi kebutuhan pasien yang dimaksud disini adalah kebutuhan akan siraman rohani yaitu yang diberikan oleh konselor (rohaniawan) dan pendampingan keluarga yang harus selalu siap sedia dalam menuntun mereka (pasien) ketika sedang mengalami sakit baik itu sakitnya ringan maupun yang sudah berat. 
Dakwah dengan Pelayanan Pasien

Amin (2009) menjelaskan bahwa dakwah adalah hal yang penting dalam setiap kehidupan pribadi Muslim, yang esensinya terletak pada seruan dorongan atau motivasi, stimulan dan bimbingan kepada orangorang supaya menyambut ajaran Islam dengan penuh kesadaran demi keuntungan dirinya sendiri serta bukan pada kepentingan yang mengajaknya.

Begitu juga dengan pelayanan pasien Kusnanto (2005) menjelaksan bahwa pelayanan keperawatan terhadap pasien yang diberikan oleh seorang perawat di rumah sakit merupakan bentuk pelayanan yang paling pusat sehingga perlunya mendapatkan sebuah perhatian yang sangat besar. Sebab perawat berinteraksi dengan pasien serta keluarganya selama 24 jam terutama perawatan yang bertugas di bagian rawat inap. Maka disinilah perawat akan memberikan pelayanan secara komprehensif, baik itu dari segi pelayanan akan kebutuhan fisik, spiritual, psikologi, sosial dan pendidikan kepada pasien. Dengan demikian pelayanan keperawatan akan dapat dirasakan lebih sempurna oleh pasien, jadi tidak hanya secara fisik saja yang mendapatkan perhatian perawat.

Maka dari itu dakwah dengan pelayanan kesehatan juga harus menjadi prioritas oleh rumah sakit dengan memperkenalkan nilai-nilai keislaman atau yang biasa kita kenal dengan istilah dakwah, harus selalu disampaikan kepada semua pasien terutama yang beraga Islam, supaya mereka secara keimanan lebih kuat lagi terlebih ketika sedang menjalani masa-masa sulit (sakit). Sehingga tidak heran apabila sekarang terus dilakukan dengan berbagai macam cara. Tidak jarang, kiat ini diwujudkan melalui beragam cara yang inovatif. Salah satunya seperti yang dilakukan rumah sakit di Salatiga. 


\section{Metodologi Penelitian}

Pada penelitian ini peneliti menggunakan pendekatan kualitatif, yaitu penelitian yang berikhtiar mengungkapkan perihal secara menyeluruh dan sesuai dengan konteks (holistik-kontekstual) melalui pengumpulan data dari latar alami dengan memanfaatkan diri peneliti sebagai instrumen kunci. Pendekatan kualitatif ini akan menghasilkan data deskriptif dalam bentuk ucapan ataupun tulisan dan perilaku orang yang diamati. Penelitian deskriptif adalah "mengurutkan atau menafsirkan data yang berkenaan dengan fakta, keadaan, variabel, dan fenomena yang terjadi saat penelitian berlangsung dan menyajikan apa adanya" (Sudrajat, 2001).

Penerapan pendekatan kualitatif dengan pertimbangan kemungkinan data yang diperoleh di lapangan berupa data dalam bentuk fakta yang perlu adanya analisis secara mendalam. Maka pendekatan kualitatif akan lebih mendorong pada pencapaian data yang bersifat lebih mendalam terutama dengan keterlibatan peneliti sendiri di lapangan dengan berusaha mendeskripsikan fenomena tersebut dalam bentuk kata-kata yang dalam pembahasannya peneliti padukan dengan kajian yang dilakukan sebelumnya.

Sedangkan metode penelitian yang digunakan adalah metode deskriptif yaitu sebagai penelitian yang dimaksudkan untuk menjelaskan fenomena atau karakteristik individual, situasi, atau keolompok tertentu secara akurat. Dengan kata lain, penelitian deskriptif adalah untuk mendeskripsikan peristiwa atau kondisi populasi saat ini (Sudarwan, 2002). 
Hasil Penelitian dan Pembahasan

\section{Model dakwah dalam pelayanan pasien di rumah sakit umum daerah Salatiga}

Pelayanan pasien yang diberikan oleh Rumah Sakit Umum Daerah Salatiga sudah ada sejak sembilan tahun yang lalu lebih tepatnya sekitar tahun 2010. Tentunya pada awal rumah sakit menyediakan tenaga konselor (rohaniawan) banyak pasien yang merasa asing terhadap keberadaan tenaga konselor atau rohaniawan sehingga tidak sedikit dari pasien-pasien disana yang menolak untuk diberikan pelayanan.

Dalam wawancara dengan WD (4 Agustus 2019) menyatakan bahwa Seiring dengan berlalunya waktu dan seringnya disosialisasikan oleh pihak manajemen rumah sakit pada pasien dan keluarga serta sudah mulai sadarnya pasien dan keluarga akan pentingnya konselor (rohaniawan) dalam pelayanan pasien guna mempermudah mereka menghilangkan kegelisahan, kecemasan secara psikologis maupun secara spiritual.

Sedangkan tenaga konselor yang disediakan oleh Rumah Sakit Umum Daerah Salatiga adalah berjumlah 7 (tujuh) orang, yang terdiri dari dua orang tenaga resmi dari rumah sakit sedangkan yang lima orang linnya adalah pegawai dari Kemterian Agama Salatiga (tiga orang dari agama Islam dan 2 orang dari Nasrani) kesemuianya itu diperbantukan untuk melayani pasien di Rumah Sakit Umum Daerah Saltiga. Apabila dihitung dengan jumlah pasien rawat inap yang ada di semua ruangan Rumah Sakit Umum Daerah Salatiga tentunya masih dirasa sangat kurang meskipun mereka selalu berkolaborasi dalam pelayanan terhadap pasien. Tentu khusunya bagi pasien yang beragama Islam. Adapun untuk masalah pembagian bidang garapan terhadap pasien, semua sudah diaatur oleh pihak manajemen rumah sakit. Setiap konselor diberi tanggungjawab 
untuk bertanggung jawab setiap bangsal (ruangan) setiap bangsal ada dua orang konselor yang bertanggung jawab untuk memberikan pelayanan kapada pasien seperti halnya bangsal (ruang) Flamboyan yang terdiri dari empat lantai. Kesemuanya itu dibawah pengawasan 2 (dua) orang tersebut. Dengan kondisi pasien yang berbeda-beda maka pelayanannya tidak bisa ditentukan seberapa lama waktu yang diperlukan oleh konselor, ada yang cepat dan ada pula lama. Seperti halnya pasien yang trauma, pasien persiapan operasi, pasca operasi, bahkan pasien yang mengalami penyakit berat. Selain itu, konselor juga harus memenuhi apabila ada permintyaan secara khusus dari pihak keluarga dan pasien dalam memeberikan pelayanannya.

Dalam wawancara dengan HZ (4 Agustus 2019) menjelaskan bawah model dakwah yang digunakan dalam melayani pasiennya; a). Khusus bagi karyawan dan dokter rumah sakit umum daerah Salatiga yaitu dengan melakukan kajian berkala setiap menjelang bulan suci ramadhan, kemudian kajian rutin setiap hari selama bulan suci ramdhan, kajian tahsin adalah membaca al-Qur'an sebagaimana yang dicontohkan Rasulullah dan para sahabatnya dengan menjaga dan memperhatikan hukum-hukum bacaan, mengeluarkan huruf-huruf sesuai dengan makhraj dan sifat-sifatnya, serta dengan memperindah suaranya. Ilmu tahsin ini sebenarnya kurang lebihnya sama dengan ilmu tajwid. Jadi tahsin alQur'an adalah cara membaca al-Qur'an sebagaimana yang dicontohkan Rasulullah dan para sahabatnya dengan menjaga dan memperhatikan hukum-hukum bacaan, mengeluarkan huruf-huruf sesuai dengan makhraj dan sifat-sifatnya, serta dengan memperindah suaranya.

Untuk pasien; konseling yang diberikan terhadap pasien adalah untuk membantu mereka agar bisa lebih menerima kenyataan yaitu kondisi sakit yang dideritanya, serta mereka diharapkan lebih sabar dan 
pasrah ketika menjalani selama mereka sedang sakit. Seperti halnya bimbingan psikologis, sebab bimbingan yang ditujukan kepada masalahmasalah psikologis pasien antara lain untuk menghilangkan kecemasan yang menyelimuti pasien, keputusasaan yang selalu pasien rasakan karena penyakitnya, ketakutan dan masalah psikologis lainnya. Bimbingan ini tentunya harus menggunakan pendekatan-pendekatan psikologis.

Konseling berikutnya adalah dengan menuntun pasien dalam melaksanakan ibadah (pendidikan ibadah) saat sakit seperti halnya ibadah shalat lima waktu, berikutnya adalah menuntun mereka bagaiaman tata cara bersuci (baik itu berwudlu maupun tayamum) yang disampaikan secara detil samapai mereka bisa melakukan terutama bertayamum, sebab cara itu adalah pengganti dari berwudlu yang secara umum pasien belum bisa menggunakan air wudlu.

Selain menuntun mereka dalam hal bersuci konselor dan rohaniwan memberikan bimbingan spiritual. Bimbingan spiritual tersebut diberikan adalah bimbingan dengan mengedepankan spirituallitas agama seperti dzikir, doa dan sebagainya. Bimbingan ini dimaksudkan supaya pasien lebih mendekatkan diri kepada Allah SWT. Termasuk juga didalamnya mengarahkan pasien yang dalam keadaan sakaratul maut untuk senantiasa mengingat kepada Allah sehingga seandainya meninggal dalam keadaan husnul khatimah. Dan konselor mendapingi pasien yang sedang menghadapi sakaratul maut yaitu mentalkinkan mereka sampai ajal menjemput.

SB menyampaikan dalam wawancaranya (6 Agustus 2019) bahwa Ada beberapa kendala yang dihadapai diantanya adalah berkaitan dengan waktu dan sumberdaya manusia yaitu keterbatasan waktu yang ada disebabkan oleh keinginan tim medis supaya pasien banyak beristirahat 
karena pasien membutuhkan ketenangan baik lahir dan batin, asumsi dari tim medis bahwa setiap pasca pengaobatan atau pemberian obat harus banyak beristiraht yang kemudian ini berimplikasi pada jadwal besuk dan meminimalisir pendamping pasien (keluarga). Selain itu pemberian jadwal untuk konseling belum begitu diprioritaskan dengan pertimbangan bahwa konseling hanya bisa mengobati diwilayah ketenangan jiwa seorang pasien, sehingga para dokter dan perawat belum bisa memberikan ruang yang begitu maksimal pada konselor (rohaniawan). Ideal waktu yang seharusnya dalam pelayanan pasien yang diberikan oleh konselor adalah setiap hari seorang konselor melakukan pendampingan. Selain itu waktunya juga bisa menyesuaikan kepada pasien yang membutuhkan pendampingan, maka dengan kata lain pasien boleh untuk reques terhadap pendampingan yang diberikan oleh para konselor (rohaniawan). Kemudian selain terbatasnya waktu yang ada kedala berikutnya adalah kurangnya tenaga sumber daya manusia (SDM). Dengan mengandalkan konselor yang berjumlah 6 (enam) orang itu sangatlah dirasakan kurang sebab banyaknya pasien yang harus dilayani di Rumah Sakit Umum Daerah Salatiga sebab sumber daya manusia merupakan faktor utama dan strategis bagi tercapainya keberhasilan suatu instansi. Sumber daya manusia yang cukup dan berdaya saing yang tinggi merupakan pendukung peningkatan baik dibidang kesehatan maupun bidang sosial. Tersedianya sumber daya manusia yang tercukupi adalah kunci keberhasilan di era globalisasi. Pengembangan dan penambahan sumber daya manusisa di bidang kesehatan merupakan komponen strategis guna mempercepat pemerataan pemerataan pelayanan kesehataan terumtama konselor serta pencapaian tujuan pembangaunan kesehatan. Mengingat tingginya tingkat persaingan usaha khususnya dibidang pelayanan kesehatan dan semua mengiginkan 
menjadi yang terbaik di mata masyarakat. Hal tersebut tentunya tidak terlepas dari yang namanya peran dan fungsi sumber daya manusia. Salah satu cara utuk mengembangkan sumaber daya manusia di bidang kesehatan (konselor) yaitu dengan melalui sistem pendidikan dan pelatihan sumber daya manusia kesehatan dibidang konselor. Fungsi dari pendidikan dan pelatihan ini adalah sebagai investasi sumber daya manusia dan merupakan tuntutan organisai. Selain itu pula bertujuan untuk memperbaiki serta mengatasi kekurangan dalam pelaksanaan pekerjaan agar sesuai dengan realitas yang ada di tempat tersebut yaitu di Rumah Sakit Umum Daerah salatiga.

Namun, sangatlah disayangkan perencanaan sumber daya manusia di pelayanan (konseling) kesehatan kurang. Seperti disampaikan di atas bahwa Rumah Sakit Umum daerah salatiga hanya memiliki tenaga konselor 2 (dua) orang dan 4 (empat) orang dari tenaga rohaniawan Kementerian Agama Salatiga. Sehingga pada saat pelayanan tidak bisa memberikan pelayanan secara maksimal.

Berikutnya adalah kendala yang berkaitan dengan lemahnya pemahaman keluarga pasien akan pengetahuan tentang agama. Dengan background atau latarbelakang keluarga seperti itu menjadi tantangan tersendiri juga, sebab ketika konselor (rohaniawan) sudah memberikan bimbingan mengenai tata cara pelaksanaan shalat lima waktu pada paasien namun dengan rendahnya pemahaman keluarga akan ilmu agama menjadikan pasien kembali tidak menunaikan kewajibannya akan perintah agama. Maka hal itu harusnya jadi perhatian khusus bagi pihak keluarga untuk selalu mengingatkan pasien terkait agama. Ini juga menjadi pekerjaan tambahan konselor dalam menginagtkan pihak keluarga untuk saling bekerjasama ketika mendapaiti pasien dan keluarga yang semacam ini. Jadi konselor tidak hanya memberikan bimbingan dan 
masukan kepada si pasien saja akan tetapi pada pihak keluarga yang menunggui juga.

Wawancara dengan DI (10 Agustus 2019) memaparkan bahwa dampak dari dakwah terhadap pasien secara umum dengan adanya pelayanan yang diberikan oleh Rumah Sakit Umum Daerah Salatiga ini pasien sangat merasa terbantu terutma bagi mereka yang pehamamannya tentang agama masih kurang atau bahkan sama sekali tidak paham agama. Seperti halnya berkaitan dengan bersuci. Dengan adanya pelayanan semacam ini pasien merasa mendapatkan ilmu yang baru contohnya bersuci dengan pengganti air yaitu tayamum, cara ibadah ketika sakit (shalat dengan berbaring). Selian itu pasien merasakan kenyaman, ketenangan, serta lebih bersyukur dan pasrah terhadapa kehendak Allah yang diberikan kepada mereka, bahkan pasien memiliki semangat yang tinggi untuk sembuh dari penyakitnya setelah dilakukan do'a bersama. Sebagian besar pasien yang dirawat di rumah sakit ini setelah diberikannya pelayanan oleh konselor (rohaniawan) terlihat lebih memiliki semangat yang tinggi untuk melawan penyakitnya. Karena mereka tidak lagi khawatir kalaupun mereka tidak memiliki umur yang panjang, seabab mereka merasa sudah melaksanakan apa yang telah diperintahkan oleh agama untuk selalu beribadah dan bersyukur dalam setiap kondisi.

Pasien secara langsung telah diberikan dakwah atau bimbingan rohani dan spiritual, kami dapatkan informasinya dari dokter, perawat, dan pihak penanggung jawab ruangan (bangsal) tempat kami di rawat. Di mana mereka menyampaikan bahwa ada petugas khusus yang akan datang sesuai jadwal atau sesuai permintaan pasien ke ruangan tempat kami dirawat. Maka dari itu sangat diperlukan dan kami sangat merasa senang, yang sakit disini dari latar belakang masyarakat yang berbeda- 
beda, ada yang memiliki tingkat pengetahuan ilmu agama bagus, ada yang sedang, bahkan ada yang sama sekali yan minim ilmu agamanya, kesemuanya itu baik yang paham ilmu agama sampai pada tidak paham sama sekali, dengan adanya dakwah di rumah sakit untuk pasien jadi lebih terbantu.

Dalam wawancara dengan NJ (10 Agustus 2019) mengatakan bahwa dakwah yang dilakukan oleh pengelola rumah sakit yaitu ada petugas khusus (konselor atau rohaniawan) yang datang kepada kami untuk memberikan siraman rohani, memberikan motivasi, serta mendo'akan kami yang sedang sakit. Bahwa tidak hanya sampai disitu saja, kami juga diberikan ilmu bagaimana beribadah ketika sedang sakit. Seperti cara shalat sedang sakit (shalat sambil berbaring), berzikir, dan amalanamalan ketika sedang mendapatkan musibah yaitu sakit. Selain itu, kami diajarkan bagaimana cara bersuci pada saat kondisi orang sakit yang tentunya kebnanyakan orang kalau sakit tidak boleh terkena air yaitu bertayamum. Kami diajarkan cara bertayamum sampai dengan tuntas. Seperti yang disampaikan bahwa sebelum beribadah terutama shalat hendaklah bersuci terlebih dahulu, maka salah satu cara bersuci pengganti wudlu adalah bertayamum (bersuci dengan menggunakan debu). Petugas atau konselor yang datang memberikan layanan kepada semua pasien yang tanpa terkecuali, pelayanan tersebut tentunya tidak terlepas dengan latar belakang agama pasien. Bagi pasien yang non muslim akan ditangani oleh rohaniawan yang non muslim pula.

Model dakwah yang dilakukan terhadap pasien diantaranya adalah petugas atau konselor dalam memberikan dakwah kepada pasien dengan model pendekatan secara langsung yaitu dengan lisan, yaitu memberikan nasehat seperti mengajak untuk selalu bersyukur atas nikmat yang diberikan Allah SWT dalam setiap kondisi apapun baik itu ketika sakit 
terlebih lagi pada saat diberikan kesehatan. Selain itu petugas konselor (rohaniawan) mengajak pasien untuk selalu mendakeatkan diri kepada Allah SWT meskipun dalam kondisi sedang sakit, lebih pasrah atas apa yang menjadi kehendak-Nya. Cara yang mereka lakukan kepada kami sangatlah mudah dipahami, mereka selalu berusaha dan bersabar untuk menuntun kami ke jalan yang benar. Terkadang tidak sedikit pasien yang sudah tidak bisa diajak berkomunikasi, namun mereka tetap menyampaikan kepada pihak keluarga atau yang menjaga pasien selama di rawat di rumah sakit. Selain itu, konselor juga memberikan contohcontoh kepada kami selaku pasien untuk selalu melakukan shalat lima waktu.

Bagi saya ada hal yang menarik ketika para konselor memberikan pelayanan rohani kepada pasien yaitu mereka tidak takut dan merasa jijik ketika berinteraksi secara langsung kepada kami yang sedang sakit. Konselor menyampaikan kalau pasien-pasien yang sedang dirawat baik itu sakitnya sedang, parah, bahwak kritis harus mereka layani seperti halnya orang-orang yang sehat di luar sana.

Pasien secara langsung merasa senang terhadap dakwah yang diberikan pada pasien. Baik itu motivasi maupun ilmu agama yang diberikan adalah untuk menjadikan diri lebih bermakna dan lebih mensyukuri atas segala yang telah dikaruniakan kepada semua umat manusia. Manfat dakwah terhadap pasien di rumah sakit lebih banyak manfaatnya. memberikan banyak sekali informasi dan ilmu yang bermanfaat terutama bagi orang-orang yang sedang terbaring lemah di rumah sakit. Menguatkan aqidah supaya tidak berharap kepada yang lain selain Allah SWT dan banyak sekali menyampaikan pesan-pesan yang menyejukkan jiwa yang gelisah. Terbukti dengan pelayanan itu jiwa ini merasa lebih kuat, lebih bersemangat, dan yang utama lagi adalah lebih 
Reza Ahmadiansah

ikhlas terhadap apa yang sedang menimpa saat ini. Selain itu lebih banyak melakukan ibdah seperti berzikir, bersholawat kepada Nabi, dan melakukan shalat sambil berbaring. Tentunya bagi pasien yang menyadari akan hal itu lebih banyak berterima kasih atas apa yang telah diberikan kepadanya. Bisa dipastikan kalau tidak adanya pelayanan rohani seperi yang diberikan oleh rumah sakit ini, maka jiwa ini tidak akan memiliki ketenangan dan ketentraman sacara batin. Hal ini dikarenakan spiritual pasien mendapatkan asupan yaitu pesan-pesan yang menjadikan semangat untuk bangkit dari keterpurukan (sakit) yang dialami.

\section{Model dakwah dalam pelayanan pasien di Rumah Sakit dr. Asmir Salatiga}

Pelaksanaan dakwah yang dilakukan oleh pihak rumah sakit $\mathrm{dr}$ Asmir Salatiga terhadap kebutuhan pasien ketika membutuhkan konseling bagi kejiwaan, atau penenang ruhani mereka saat dirundung banyak penyakit yang berat, atau beberapa maslah yang lainnya, yaitu ketika meminta dari pihak rumah sakit untuk melakukan bimbingan atau arahan-arahan yang sifatnya untuk membuat kenyamanan dalam psikis pasien.

Dalam wawancara dengan YM (26 Agustus 2019) mengjelaskan bahwa petugas yang melaksanakan dakwah, atau konseling yang mempunyai prioritas dengan jiwa keagamaan adalah orang-orang berasal dari bintal korem. Beberapa dari pihak korem memang mempunyai kualitas yang mumpuni dalam memberikan pesan-pesan dakwah melalui konseling yang mereka berikan. Dan intinya bahwa untuk saling melengkapi kebutuhan yang bisa saling mengisi, maka beberapa kerja sama tersebut dilakukan. Alternatif yang lain, ketika dari bintal korem tidak bisa berkontribusi maka akan melapor pada kita. Setelah itu dari 
pihak rumah sakit memberikan instruksi bagi beberapa petugas untuk memberikan konseling pada petugas.

Beberapa hal yang dilakukan oleh petugas untuk memenuhi kebutuhan pasien yaitu dengan menasihati, memberikan wejangan, memimpin doa dengan keluarga-keluarganya yang sedang hadir atau sedang nerawatnya. Berbeda dengan yang sudah mengalami kritis, petugas melakukan tindakan sesuai permintaan keluarganya, seperti contoh baca surat Yasin, dzikir bersama dan lain sebagainya. Beberapa pasien yang sudah membutuhkan hal tersebut ketika pasien sudah masuk ICU. Bagi beberapa pasien yang sudah kritis tapi keluarganya tidak ada, petugas juga melaksanakan penanganan seperti do'a dan yang lainnya, dan jika meninggal, biasanya diurus di rumah sakit dan di makamkan di pemakaman umum.

Setelah dilakukan pelayanan oleh petugas konseling yang berkaitan dengan dakwah, beberapa pasien ada merasakan nyaman. Untuk pasienpasien sendiri sebenarnya kadang tidak paham dengan ada mekanisme kaitannya dengan dakwah, karena inti dalam tindakan tersebut adalah penyembuhan pasien, baik lewat obat-obatan atau perbaikan psikis. Perkembangan yang lebih baik dari kejiwaan pasien sering terlihat dari perubahan mimik muka, yang sebelumnya terlihat murung berubah menjadi kelihatan lebih tenang, rileks dan bahwakan ada juga yang berubah menjadi bahagia, walau sebenarnya secara jasmani masih sakit.

Ada beberapa hari-hari tertentu dilakukan ceramah atau tausiyah yang dilaksanakan di Masjid rumah sakit. Kegiatan ceramah atau tausiyah tersebut dilakukan setelah salat dzuhur. Pengisi materi tausiyah adalah ustadz yang di datangkan dari pihak lain, yang penting orang tersebut mempunyai kualitas di bidang dakwah dan konseling. Untuk hari yang pasti dilakukan tausiyah adalah hari Jum'at, tapi terkadang juga dilakukan 
$\overline{\text { pada hari rabu. Pelaksanaan tausiyah yang dilakukan di masjid tentunya }}$ tidak lepas dari peranan dakwah yang dilakukan oleh pihak rumah sakit, agar bisa memberikan ketenangan pasien atau keluarganya. Sehingga dengan keadaan yang tenang tersebut bisa merubah kondisi pasien dan keluarga pasien lebih baik, dan diharapkan segera sembuh.

Wawancara dengan IE (26 Agustus 2019) yang mengungkapkan bahwa pasien merasa senang jika ada pelayanan dakwah terhadap pasien itu memang betul-betul ada maka akan merasa sangat senang sekali. Karena dengan adanya pelayanan dakwah, pasien akan merasa sangat terbantu dalam memenuhi nutrisi rohani dan spiritualitas pasien.

Dengan dilakuaknnya dakwah di rumah sakit pasti akan berdampak sangat positif sebab ilmu agama yang diberikan oleh petugas bisa mengurangi tingkat kecemasan pasien, dan akan meningkatkan motivasi serta semangat yang tinggi untuk sembuh dari sakit, sedangkan untuk pasien yang sudah menderita sakit keras mereka akan lebih tenang dalam siap ketika ajal sudah datang.

\section{Simpulan}

Pelayanan pasien yang diberikan oleh Rumah Sakit Umum Daerah Salatiga sudah ada sejak sembilan tahun yang lalu lebih tepatnya sekitar tahun 2010. Sedangkan tenaga konselor yang disediakan oleh Rumah Sakit Umum Daerah Salatiga adalah berjumlah tujuh orang, yang terdiri dari dua orang tenaga resmi dari rumah sakit sedangkan yang lima orang linnya adalah pegawai dari Kemterian Agama Salatiga (tiga orang dari agama Islam dan dua orang dari Nasrani). Model dakwah yang digunakan dalam melayani pasiennya; a). Khusus bagi karyawan dan dokter rumah sakit umum daerah Salatiga yaitu dengan melakukan kajian berkala setiap menjelang bulan suci ramadhan, kemudian kajian rutin setiap hari selama 
bulan suci ramdhan, kajian tahsin adalah membaca al-Qur'an sebagaimana yang dicontohkan Rasulullah dan para sahabatnya dengan menjaga dan memperhatikan hukum-hukum bacaan, mengeluarkan huruf-huruf sesuai dengan makhraj dan sifat-sifatnya, serta dengan memperindah suaranya. Untuk pasien; konseling yang diberikan terhadap pasien adalah untuk membantu mereka agar bisa lebih menerima kenyataan yaitu kondisi sakit yang dideritanya, serta mereka diharapkan lebih sabar dan pasrah ketika menjalani selama mereka sedang sakit. Seperti halnya bimbingan psikologis, sebab bimbingan yang ditujukan kepada masalah-masalah psikologis pasien antara lain untuk menghilangkan kecemasan yang menyelimuti pasien, keputusasaan yang selalu pasien rasakan karena penyakitnya, ketakutan dan masalah psikologis lainnya.

Bimbingan ini tentunya harus menggunakan pendekatanpendekatan psikologis. Konseling berikutnya adalah dengan menuntun pasien dalam melaksanakan ibadah (pendidikan ibadah) saat sakit seperti halnya ibadah shalat lima waktu, berikutnya adalah menuntun mereka bagaiaman tata cara bersuci (baik itu berwudlu maupun tayamum) yang disampaikan secara detil samapai mereka bisa melakukan terutama bertayamum, sebab cara itu adalah pengganti dari berwudlu yang secara umum pasien belum bisa menggunakan air wudlu. Selain menuntun mereka dalam hal bersuci konselor dan rohaniwan memberikan bimbingan spiritual. Bimbingan spiritual tersebut diberikan adalah bimbingan dengan mengedepankan spirituallitas agama seperti dzikir, doa dan sebagainya. Bimbingan ini dimaksudkan supaya pasien lebih mendekatkan diri kepada Allah SWT. Termasuk juga didalamnya mengarahkan pasien yang dalam keadaan sakaratul maut untuk senantiasa mengingat kepada Allah sehingga seandainya meninggal 
Reza Ahmadiansah

$\overline{\text { dalam keadaan husnul khatimah. Dan konselor mendapingi pasien yang }}$ sedang menghadapi sakaratul maut yaitu mentalkinkan mereka sampai ajal menjemput. Model dakwah yang dilakukan terhadap pasien diantaranya adalah petugas atau konselor dalam memberikan dakwah kepada pasien dengan model pendekatan secara langsung yaitu dengan lisan, yaitu memberikan nasehat seperti mengajak untuk selalu bersyukur atas nikmat yang diberikan Allah SWT dalam setiap kondisi apapun baik itu ketika sakit terlebih lagi pada saat diberikan kesehatan. Selain itu petugas konselor (rohaniawan) mengajak pasien untuk selalu mendakeatkan diri kepada Allah SWT meskipun dalam kondisi sedang sakit, lebih pasrah atas apa yang menjadi kehendak-Nya. Cara yang mereka lakukan kepada kami sangatlah mudah dipahami, mereka selalu berusaha dan bersabar untuk menuntun kami ke jalan yang benar.

Pelaksanaan dakwah yang dilakukan oleh pihak rumah sakit $\mathrm{dr}$ Asmir Salatiga terhadap kebutuhan pasien ketika membutuhkan konseling bagi kejiwaan, atau penenang ruhani mereka saat dirundung banyak penyakit yang berat, atau beberapa maslah yang lainnya, yaitu ketika meminta dari pihak rumah sakit untuk melakukan bimbingan atau arahan-arahan yang sifatnya untuk membuat kenyamanan dalam psikis pasien. Beberapa hal yang dilakukan oleh petugas untuk memenuhi kebutuhan pasien yaitu dengan menasihati, memberikan wejangan, memimpin doa dengan keluarga-keluarganya yang sedang hadir atau sedang nerawatnya. Berbeda dengan yang sudah mengalami kritis, petugas melakukan tindakan sesuai permintaan keluarganya, seperti contoh baca surat Yasin, dzikir bersama dan lain sebagainya. Beberapa pasien yang sudah membutuhkan hal tersebut ketika pasien sudah masuk ICU. 
Bagi beberapa pasien yang sudah kritis tapi keluarganya tidak ada, petugas juga melaksanakan penanganan seperti do'a dan yang lainnya, dan jika meninggal, biasanya diurus di rumah sakit dan di makamkan di pemakaman umum. Setelah dilakukan pelayanan oleh petugas konseling yang berkaitan dengan dakwah, beberapa pasien ada merasakan nyaman. Untuk pasien-pasien sendiri sebenarnya kadang tidak paham dengan ada mekanisme kaitannya dengan dakwah, karena inti dalam tindakan tersebut adalah penyembuhan pasien, baik lewat obat-obatan atau perbaikan psikis. Perkembangan yang lebih baik dari kejiwaan pasien sering terlihat dari perubahan mimik muka, yang sebelumnya terlihat murung berubah menjadi kelihatan lebih tenang, rileks dan bahwakan ada juga yang berubah menjadi bahagia, walau sebenarnya secara jasmani masih sakit. Ada beberapa hari-hari tertentu dilakukan ceramah atau tausiyah yang dilaksanakan di Masjid rumah sakit. Kegiatan ceramah atau tausiyah tersebut dilakukan setelah salat dzuhur. Pengisi materi tausiyah adalah ustadz yang di datangkan dari pihak lain, yang penting orang tersebut mempunyai kualitas di bidang dakwah dan konseling.

\section{Daftar Pustaka}

Amin, S. M. (2009). Ilmu Dakwah. Jakarta: Hamzah.

Arifin, I. Z \& Satriah, L. (2018). Model Dakwah bi al-Irsyād untuk Pemeliharaan Kesehatan Mental Spiritual Pasien di Rumah Sakit. Academic Journal for Homiletic Studies, 12, (1), 99-120. DOI: 10.15575/idajhs.v12i1.1908

Arifin, I. Z. (2012). Bimbingan dan Konseling Islam untuk Pasien Rawat Inap di Rumah Sakit. Academic Journal for Homiletic Studies, 6, (1), 170-194. DOI: https://doi.org/10.15575/idajhs.v6i1.332 
Reza Ahmadiansah

Gade, S., \& Don, Hj. G. A. (2015). Model Dakwah: Satu Analisis Teoritikal.

Ulum Islamiyyah The Malaysian Journal of Islamic Sciences, 16, 23-41.

http://www.myjurnal.my/public/article-view.php?id=91912

Hardjodisastro, D. (2006). Menuju seni Ilmu Kedokteran: bagaimana

dokter berpikir, bekerja, dan menampilkan diri. Jakarta: PT. Gramedia Pustaka Umum.

Hawari, D. (2011). Manajemen Stres Cemas dan Depresi. Jakarta: Balai Penerbit FKUI.

Hidayanti, E. (2014). Dakwah pada Setting Rumah Sakit: (Studi Deskriptif

Terhadap Sistem Pelayanan Bimbingan Konseling Islam Bagi Pasien

Rawat Inap di RSI Sultan Agung Semarang). Jurnal Bimbingan

Konseling Islam, 5, (2). DOI 10.21043/kr.v5i2.1049

Ismainar, H. (2013). Administrasi kesehatan Masyarakat. Seleman

Yogyakarta: Penerbit Deepublish (CV. Budi Utama).

Kusnanto. (2005). Pengantar profesi \& praktik keperawatan profesional. Jakarta: EGC.

Lestari, P. R. T. (2014). Harapan atas Profesi Keperawatan di Indonesia. Jurnal Kajian, 11, 51-

52. https://jurnal.dpr.go.id/index.php/kajian/article/view/548/4 43.

Mahmud, A. (2008). Tehnik Simulasi dan Permodelan. Yogyakarta: Universitas Gajah Mada.

Nafsiah, S. (2000). Prof. Hembing pemenang the Star of Asia Award:

Pertama di Asia Ketiga di Dunia. Jakarta: Prestasi Insan Indonesia.

Pohan, I. (2007). Jaminan Mutu Layanan Kesehatan. Jakarta: Penerbit Buku Kedokteran ECG.

Republik Indonesia. (2004). Undang-Undang RI Nomor 29 Tahun 2004 tentang Praktik Kedokteran. 
Reza Ahmadiansah

$\overline{\text { Republik Indonesia. (2009). Undang-Undang RI Nomor } 44 \text { Tahun } 2009}$ tentang Rumah Sakit.

Ridla, M. R. Rifa'I, A., \& Suisyanto. (2017). Pengantar Ilmu Dakwah:

Sejarah, Perspektif, dan ruang Lingkup. Yogyakarta: samudra Biru.

Saputra, W. (2011). Pengantar Ilmu Dakwah. Jakarta: PT Raja Grafindo Persada.

Simatupang, E. J. (2008). Manajemen Pelayanan Kebidanan. Jakarta: EGC.

Sudarwan, D. (2002). Menjadi Peneliti Kualitatif. Bandung: Pustaka Setia.

Wilhamda. 2011. Tingkat Kepuasan Pasien Terhadap Mutu Pelayanan Keperawatan di Rumah Sakit Umum Haji Medan. Program Dtudi Diploma III Keperawatan Haji Medan, Skripsi (tidak di tampilkan).

\section{Sumber dari Internet}

http://rsud.salatiga.go.id/

http://salatigakota.go.id/InfoBerita.php?id=937 